\title{
What same sex civil partnerships may mean for health
}

\author{
Michael King, Annie Bartlett
}

J Epidemiol Community Health 2006;60:188-191. doi: 10.1136/jech.2005.040410

A growing number of countries have introduced a form of marriage or civil partnership registration for same sex couples. Marriage confers health benefits on heterosexual men and women and similar benefits could arise from same sex civil unions. The authors argue that legal and social recognition of same sex relationships may reduce discrimination, increase the stability of same sex relationships, and lead to better physical and mental health for gay and lesbian people.

See end of article for authors' affiliations

Correspondence to Professor M King, Primary

Care Psychiatry, Royal Free and University College Medical School, University College London, Hampstead Campus, Rowland Hill Street, London NW3 2PF, UK; m.king@medsch.ucl.ac.uk

Accepted for publication 18 October 2005
$\mathrm{S}$ nce the introduction of the first civil partnership law in 1989 in Denmark, legal recognition of same sex relationships has been debated around the world. Civil partnership agreements were conceived out of a concern that same sex couples have no protection in law in circumstances of death or break up of the relationship. However, there has been little consideration of the possible health consequences of such partnerships. We shall argue that:

- Lesbians and gay men experience prejudice and discrimination, including moral and religious censure.

- Until 1989, same sex relationships had no formal recognition in any society.

- Legal civil unions may increase the stability of same sex relationships and reduce social exclusion of gay and lesbian people.

- Marriage confers health benefits on men and women and similar benefits could arise from same sex civil unions.

- Civil unions will change the health service's approach to gay men and lesbians and lead to improved health care.

\section{THE ROW OVER CIVIL PARTNERSHIPS}

Eleven European Union member states, several states in the USA and Australia, and Canada have now introduced marriage or a form of civil partnership registration for same sex couples. Civil partnerships became law in Britain in 2005. ${ }^{1}$ However, there has been, and continues to be, strenuous opposition to such changes on moral and religious grounds. Prejudice against homosexuality differs from that against race or sex, as it is often regarded as unnatural and morally perverse. In July 2004 the United States Senate debated the Federal Marriage Amendment, an unsuccessful attempt to ban gay marriage by Federal Law. More recently, 4000 same sex "annulled" by the California Supreme Court because they were considered in violation of a marriages sanctioned in San Francisco were
1977 state law defining marriage as a union between a man and a woman. The Vatican equates same sex unions with deviant behaviour. ${ }^{2}$

\section{THE HEALTH CONSEQUENCES OF MARRIAGE}

Fifty six per cent of people in the USA and $51 \%$ in the UK are married and living with their spouses. Although many studies have not clearly distinguished between marriage and cohabitation, married people seem to have better physical and psychological health than single people. ${ }^{3}$ Unmarried people have increased rates of all cause mortality compared with married. ${ }^{4}$ Some of this advantage is attributable to social selection in that healthy, well adjusted people make more attractive partners and may be more likely to endure difficulties and remain in the marriage. Nevertheless, there is considerable evidence that being married leads to better physical and mental health and increased longevity. ${ }^{5}$ There has long been good evidence that social relationships positively affect health through practical and emotional support ${ }^{6}$ and marriage may be the commonest and possibly strongest of such social bonds. However, up to one in two marriages in Western countries ends in divorce and troubled marriages can have negative health consequences, possibly mediated through the effect of hostility on cardiovascular activity, changes in stress hormones, and changes in the immune system. ${ }^{78}$ There has also been debate about whether the effects of marriage vary between men and women on the basis of economic autonomy and gender roles. Marriage seems to lead to greater reductions in mortality in men than women ${ }^{8}$ and marriage may be better for men's mental health than women's. ${ }^{9-11}$ In an Italian case register study, married women were more likely than their single counterparts to be admitted for depression, the reverse of the situation for men. ${ }^{9}$ However, longitudinal studies have not supported this conclu$\operatorname{sion}^{12}$ and negative psychological consequences for the woman seem to be greatest when she cares for young children. ${ }^{13} \mathrm{~A}$ recent Canadian study followed up a sample of over 11000 men and women for over two years, confirming the mental health benefits of marriage for both sexes and showing that women had no greater vulnerability than men to the psychological distress associated with moving into and out of marriage. ${ }^{14}$

\section{GAY AND LESBIAN HEALTH AND PSYCHOLOGICAL WELLBEING}

The potential health and social impacts of civil partnerships for same sex couples must be seen in the context of what is known about gay and lesbian health. Lesbians seem to have higher risk factors for breast cancer (nulliparity and higher 
alcohol intake) and cardiovascular disease (overweight and cigarette smoking) than heterosexual women, ${ }^{15}$ while gay men are at higher risk of acquiring sexually transmitted infections ${ }^{16}$ and HIV $^{17}$ than straight men. Gay men and lesbians seem to have higher rates of anxiety, depression, substance use disorders, and suicidal behaviour than heterosexuals. ${ }^{18} 19$ The evidence is open to criticism because of the difficulty of recruiting samples that are representative of all gay and lesbian people. Lifestyle factors may play a part in this higher morbidity, particularly misuse of alcohol and other drugs. However, both groups experience intolerance of their sexual orientation, discrimination, and victimisation, ${ }^{18} 20$ which in turn may lead to greater psychological distress and higher use of services than heterosexuals. ${ }^{18}$

\section{GAY AND LESBIAN RELATIONSHIPS}

There seems to be considerable variability in the quality and durability of same sex, cohabiting relationships. ${ }^{21}{ }^{22}$ Lesbian partnerships may differ from those involving gay men, not least because lesbians are more likely to have responsibility for children, which has an impact on the nuclear couple and creates a different set of personal imperatives. ${ }^{11} 2324$ It is generally assumed that male same sex relationships are less enduring than heterosexual partnerships. This may relate to a lack of public recognition and a consistent social framework on which such relationships can be built. However, the stability of same sex relationships depends on a complex array of factors besides social and legal recognition. ${ }^{25}$ We do not know whether gay male, same sex relationships are less enduring because of something intrinsic to being male or a gay male, the gay male subculture that encourages multiple partners, or a failure of social recognition of their relationships. The "social experiment" that civil unions provide will enable us to disentangle the health and social effects of this complex question.

\section{DURABILITY OF SAME SEX CIVIL UNIONS}

Civil unions will have important legal, social, and financial implications and take place within a defined social ritual. They will probably increase societal and family support for same sex couples and enable them to resolve difficulties that inevitably arise rather than simply leave a relationship. Thus their consequences and personal significance are distinct from informal cohabitation. Because legislation of this type is recent, the longer term stability of same sex civil partnerships is not known. Countries or states where partnerships have been in force the longest are a good starting point for research. A recent, landmark study compared 212 lesbians and 123 gay men who had civil unions in Vermont with 166 lesbians and 72 gay men from among their friends who had not entered civil unions, and 219 heterosexual married women and 193 heterosexual married men recruited from among the civil union participants' siblings and their spouses. ${ }^{26}$ Members of heterosexual couples had been together longer and had a more traditional division of labour and child care than the lesbians and gay men in both types of couples. People in same sex civil unions had greater openness about sexual orientation and closer relationships with families of origin than those in same sex couples not in civil unions. Unfortunately there was no cohabiting, heterosexual group to make the comparisons complete. Although the authors concluded that the visibility of same sex unions led to the greatest benefits in terms of changed attitudes of those around them, it is difficult to know whether such attitudes had made it possible for the couples to enter civil unions in the first place.

\section{HEALTH CONSEQUENCES OF LEGISLATIVE CHANGE FOR GAY MEN AND LESBIANS}

The social respectability conferred by state sanction of same sex relationships combined with the financial benefits of
What this paper adds

- There is evidence that married men and women have better health than the unmarried although selection factors may explain some of the differences.

- Social and legal recognition of same sex relationships will reduce discrimination against gay men and lesbians.

- The public health benefits of marriage may be conferred on gay men and lesbians who enter civil partnerships.

such unions and the necessary commitment to a shared future may have positive health effects. Less discrimination against and greater societal support for long term same sex relationships may increase self respect in gay and lesbian people, reduce the tendency to have contact with multiple partners, and lead gay people to seek help more promptly for sexual infections. There is recent evidence that either a same or opposite sex, stable relationship has protective health effects. HIV infected patients receiving adequate antiretroviral treatment who are in stable sexual partnerships of at least six months' duration, progress more slowly to AIDS and death. ${ }^{27}$ However, disentangling differences in health consequences between long term relationships within and without a civil partnership will require longitudinal cohort studies that pay attention to the division of labour and power within same sex couples, their social and financial circumstances, and parenting roles. All these factors may operate differently within same sex couples as compared with opposite sex ones, ${ }^{23}{ }^{24}$ within male compared with female same sex couples, and independently of any form of legal union. For example, recent research into marriage does not always distinguish heterosexual cohabitation from marriage ${ }^{14}$ on the questionable assumption that the health benefits are the same. ${ }^{28}$ However, because marriage is equated with personal and civil maturity, the unmarried can be regarded as lacking those virtues. ${ }^{29}$ These distinctions may have even greater resonance in same sex relationships. Although civil partnerships will bring same sex couples closer to the social mainstream, many gay men and lesbians in long term relationships will still choose to remain outside them. Furthermore, there is the possibility that same sex civil partnerships will be regarded as "inferior" to same sex (or opposite sex) marriage. Comparisons between countries that legislate for same sex marriage and civil partnerships will provide data on whether the latter come to be regarded as second class. There is considerable evidence that gay men and lesbians do not receive the same standard of health care as heterosexual men and women because of fear of prejudice and discrimination ${ }^{30} 31$ and even the general public may protest against health campaigns to improve access to health programmes for gay people. ${ }^{32}$ Civil partnerships may make such negative experiences less likely by increasing the legitimacy of same sex relationships and their place in society.

The attempts of western governments and the World Health Organisation ${ }^{33}$ to address the social determinants of health, in particular the effects of social exclusion, has relevance here. Firstly, domestic violence has serious health and social consequences. It occurs in some same sex partnerships, ${ }^{34}$ just as it does in some marriages. Legislation for civil partnerships may entitle same sex couples to the same protection against domestic violence as married couples. For example, the British government proposes to extend to same sex couples ${ }^{1}$ its recent recommendation for 


\section{Policy implications}

- Same sex unions constitute a new social form, which poses challenges for health staff, who may require training to work effectively

- Government policies that respect the human rights of same sex couples may have unforeseen health benefits

stronger legal protection for victims of domestic violence by extending the use and enforcement of restraining orders. ${ }^{35}$ Secondly, civil unions introduce rights to parents and children to apply to the court for a contact or residency order should the partnership break up. Thus people will no longer be excluded from access or child care ${ }^{36}$ and will continue to play an active part in the lives of their children, regardless of their former partners' sentiments. Although unmarried same sex or opposite sex couples are currently able to adopt children in Britain, the government intends that a registered civil partnership be taken into account when considering suitability for adoption. ${ }^{1}$ Continuity in parenting is likely to have positive benefits in terms of the health and welfare of the child. ${ }^{37}$ Thirdly, under civil partnership legislation for same sex couples, individuals gain the position of next of kin, a crucial issue at the time of death or incapacity of their partner. This will increase the recognition of their loss and ease the process of bereavement for the surviving partner who, before civil unions, may have been regarded simply as a friend. Lastly it is also consistent with proposed changes in the new Mental Health Act in Britain that will address the discriminatory use of the term "nearest relative" in current mental health law. ${ }^{38}$ This will assist appropriate assessment of individuals potentially subject to detention.

\section{THE FUTURE}

Public attitudes to gay men and lesbians are changing and may reflect increasing visibility of same sex couples and the possibility of civil unions. ${ }^{39}$ In Europe, this may owe something to changes to law on discrimination against gays and lesbians in the workplace and publicity surrounding current legislative proposals. Northern Europe has seen the emergence of pluralistic societies where the State had taken the lead in encouraging acceptance of widely divergent social and cultural beliefs. Governments that have initiated discussion about civil partnerships have not responded to popular demand; rather they have sought to define an idea that might be good for society, debate its relative merits, and help their citizens to examine their norms and beliefs. ${ }^{40}$ This has been accepted because it has been a part of a wider debate about the nature of heterosexual partnerships and marriage itself, at a time of rapid social change. ${ }^{1}$ Although we recognise that marriage is by no means a panacea for health issues, legal recognition of civil partnerships seems likely to go some way to stabilise same sex relationships, create a focus for celebration with families and friends, and provide vital protection at time of dissolution. Gay men and lesbians' vulnerability to mental disorders may diminish in societies that recognise their relationships as valuable and become more accepting of them as respected members of society who might meet prospective partners at places of work and in other such settings that are usual for heterosexual people. Long term, same sex relationships have existed in many societies for millenniums and there is evidence that some may have been constituted as marriage ${ }^{41}$ However, in recent history same sex marriage or legal civil unions constitute a new social form that poses challenges for health staff, who may require training to work effectively. Mainstream health providers could learn from their colleagues in AIDS focused service organisations to provide competent compassionate and comprehensive health care to same sex partners whom they encounter in their practices. Recent debates about the links between human rights and health highlight the need for the recognition of sexual orientation as a part of humanity that must be respected. ${ }^{42}$ Improved acceptance and greater visibility of same sex family units may lead to a better understanding of the complex relationship between health, social and economic status, gender roles, and gay and lesbian identity.

\section{Authors' affiliations}

M King, Primary Care Psychiatry, Royal Free and University College

Medical School, University College London, London, UK

A Bartlett, Department of Mental Health, St George's Hospital Medical School, London, UK

Funding: none.

Competing interests: none declared

\section{REFERENCES}

1 Women and Equality Unit. Civil partnerhip: a framework for the legal recognition of same-sex couples. London: Women and Equality Unit, 2003.

2 Vatican. http://www.vatican.va/roman_curia/congregations/cfaith/ documents/rc con cfaith doc 20030731 homosexualunions en. html.

3 Kiecolt-Glaser JK, Newton TL. Marriage and health: his and hers. Psychol Bull 2001; 127:472-503.

4 Johnson NJ, Backlund E, Sorlie PD, et al. Marital status and mortality: the national longitudinal mortality study. Ann Epidemiol 2000;10:224-38.

5 Johnson DR, Wu J. An empirical test of crisis, social selection and role explanations of the relationship between marital disruption and psychological distress: a pooled time-series analysis of four-wave panel data. J Marriage Fam 2002;64:211-24.

6 Berkman LF, Glass T, Brissette I, et al. From social integration to health: Durkheim in the new millennium. Soc Sci Med 2000;51:843-57.

7 Grewen KM, Anderson BJ, Girdler SS, et al. Warm partner contact is related to lower cardiovascular reactivity. Behav Med 2003;29:123-30.

8 Robles TF, Kiecolt-Glaser JK. The physiology of marriage: pathways to health. Physiol Behav 2003;79:409-16.

9 Bebbington P, Tansella M. Gender, marital status and treated affective disorders in South Verona: a case register study. J Affect Disord 1989;17:83-91.

10 Frude N. Understanding family problems: a psychological approach. London: Wiley, 1990

11 Sogaard AJ, Kritz-Silverstein D, Wingard DL. Finnmark heart study: employment status and parenthood as predictors of psychological health in women, 20-49 years. Int J Epidemiol 1994;23:82-90.

$12 \mathrm{Kim}$ HK, McKenry M. The relationship between marriage and psychological well-being. J Fam Issues 2002;23:885-91 1 .

13 Horwitz AV, White HR. Becoming married, depression, and alcohol problems among young adults. J Health Soc Behav 1991;32:221-37.

14 Strohschein L, McDonough P, Monette G, et al. Marital transitions and mental health: are there gender differences in the short-term effects of marital status change? Soc Sci Med 2005;61:2293-303.

15 Case P, Austin SB, Hunter DJ, et al. Sexual orientation, health risk factors, and physical functioning in the nurses' health study II. J Womens Health 2004; 13:1033-47

16 Wheater CP, Cook PA, Clark P, et al. Re-emerging syphilis: a detrended correspondence analysis of the behaviour of HIV positive and negative gay men. BMC Public Health 2003;3:34.

17 Department of Health. Health check - on the state of the public health: annual report of the chief medical officer. London: Department of Health, 2003.

18 King M, McKeown E, Warner J, et al. Mental health and quality of life of gay men and lesbians in England and Wales: controlled, cross-sectional study. Br J Psychiatry 2003;183:552-8.

19 Meyer IH. Prejudice, social stress, and mental health in lesbian, gay, and bisexual populations: conceptual issues and research evidence. Psychol Bull 2003;129:674-97.

20 Mays VM, Cochran SD. Mental health correlates of perceived discrimination among lesbian, gay, and bisexual adults in the United States. Am J Public Health 2001;91:1869-76.

21 Klinger RL. Lesbian couples. In: Cabaj R, Stein TS, eds. Textbook of homosexuality and mental health. Washington: American Psychiatric Press, 1996:339-52.

22 McWhirter DP, Mattison AM. Male couples. In: Cabaj R, Stein TS, eds Textbook of homosexuality and mental health. Washington: American Psychiatric Press, 1996:319-37.

23 Dunne MP. Living difference: lesbian perspectives on work and family life. New York: Harrington Park Press, 1998.

24 Wright JM. Lesbian step families: an ethnography of love. New York: Harrington Park Press, 1998. 
25 Gottman JM, Levenson RW, Gross J, et al. Correlates of gay and lesbian couples' relationship satisfaction and relationship dissolution. J Homosex 2003;45:23-43.

26 Solomon SE, Rothblum ED, Balsam KF. Pioneers in partnership: lesbian and gay male couples in civil unions compared with those not in civil unions and married heterosexual siblings. J Fam Psychol 2004;18:275-86.

27 Young J, De Geest S, Spirig R, et al. Stable partnership and progression to AIDS or death in HIV infected patients receiving highly active antiretroviral therapy: Swiss HIV cohort study. BMJ 2004;328:15.

28 Wu Z, Hart R. The effects of marital and nomarital union transition on health. Journal of Marriage and Family 2002;64:420-32.

29 Graham M. Gay marriage: whither sex? Some thoughts from Europe. Sexuality Research and Social Policy 2004;1:24-31.

30 Fitzpatrick R, Dawson J, Boulton $M$, et al. Perceptions of general practice among homosexual men. Br J Gen Pract 1994;44:80-2.

31 Project for Advice Counselling and Education. Diagnosis: homophobic (the experiences of lesbians, gay men and bisexuals in mental health services). London: PACE, 1998.

32 Phillips-Angeles E, Wolfe P, Myers R, et al. Lesbian health matters: a pap test education campaign nearly thwarted by discrimination. Health Promot Pract 2004;5:314-25.
33 World Health Organisation. http://www.who.int/social_determinants/en/.

34 Alexander CJ. Violence in gay and lesbian relationships. J Gay Lesb Soc Serv 2002;14:95-8.

35 Home Office. Safety and justice: the government's proposals on domestic violence. London: Home Office, 2003.

36 King MB. Parents who are gay or lesbian. In: Reder P, Lucey C, eds. Assessment of parenting. London: Routledge, 1995:1-72.

37 Golombok S. Adoption by lesbian couples. BMJ 2002;324:1407-8.

38 Bartlett A, King M, Phillips P. Straight talking: an investigation of the attitudes and practice of psychoanalysts and psychotherapists in relation to gays and lesbians. Br J Psychiatry 2001;179:545-9.

39 Townsend M. Mental health issues and same-sex marriage. In: Cabaj RP, Purcell DW, eds. On the road to same-sex marriage: a supportive guide to psychological, political, and legal issues. San Francisco: Jossey Bass, 1998:89-107.

40 Reich RB. The power of public ideas. Harvard: Harvard University Press, 1988.

41 Bray A. The friend. Chicago: University of Chicago Press, 2003

42 Miller AM. Uneasy promises: sexuality, health, and human rights. Am J Public Health $2001 ; 91: 861-4$.

\section{THE JECH GALLERY}

\section{A sign of the times}

$\mathrm{N}$ Work after the September 1lth 2001 catastrophe. Bioterrorism is now perceived to be a major threat to public health. Vigilance by citizens everywhere is encouraged. But is it as great a threat to public health as pandemic flu?

John R Ashton

North West Public Health Team, Department of Health, 18th Floor, Sunley Tower, Piccadilly Plaza, Manchester MI 4BE, UK; johnrashton@blueyonder.co.uk

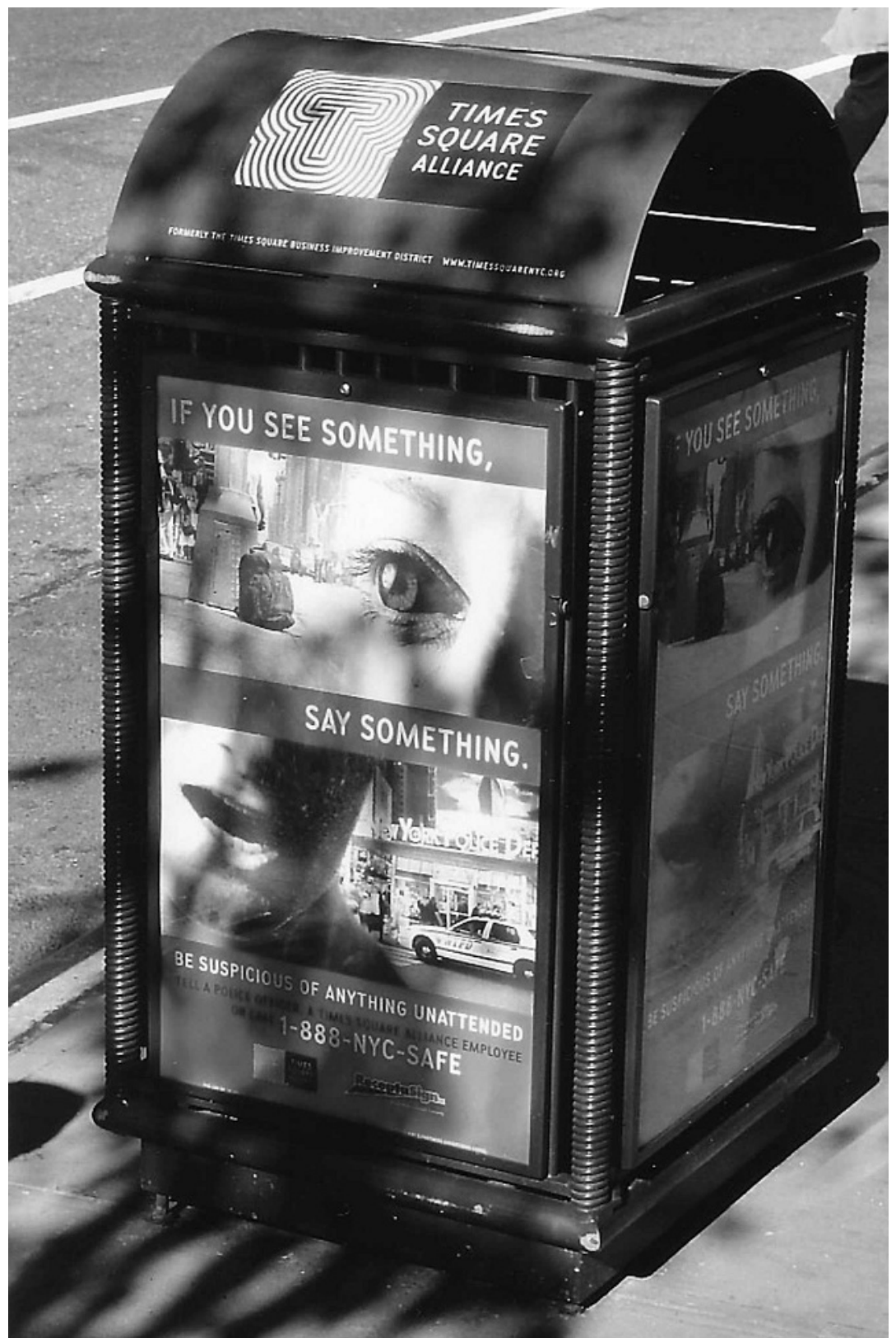

